\title{
Ectopic ureter: Case report
}

\section{Ektopik üreter: Olgu sunumu}

\author{
Hüseyin Saygın, İsmaill Emre Ergin, Emre Kuraç, Esat Korğalı
}

Cumhuriyet University, Faculty of Medicine, Department of Urology, Sivas, Turkey

Corresponding author:, İsmail Emre Ergin, MD, Cumhuriyet University, Faculty of Medicine, Department of Urology, Sivas, Turkey

E-mail: emreergin55@hotmail.com

Received/Accepted: March 03, 2021 / July 01,2021

Conflict of interest: There is not a conflict of interest.

\section{SUMMARY}

Urinary system congenital anomalies are more common than other systems. The double collecting system is caused by the emergence of two separate ureter buds from a single Wolff duct or incomplete fusion of the ureter bud with the upper and lower pole parts of the kidney. The opening of the ureter orifice to the bladder neck or to a point other than trigon is called an ectopic ureter. In this case, we report the findings of a 6-year-old girl who complained of continuous urinary incontinence. Our patient had a left-sided double collector system and the ectopic ureter draining the upper pole was opened infra sphincteric to the vaginal vestibule. In the treatment of the ectopic ureter. in our case the renal upper pole of the ectopic localized ureter was functional. End-to-side uretero-ureterostomy was performed. Ectopic ureter should be considered in the differential diagnosis of girls with continuous urinary incontinence.

Keywords: Ectopic ureter, urinary incontinence, double collecting system, ureterouretostomy

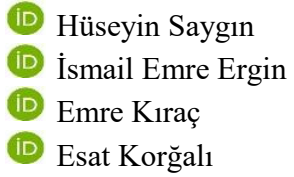

ORCID IDs of the authors: H.S. 0000-0003-0318-0353

İ.E.E. $0000-0002-6875-0882$

E.K. 0000-0002-3115-0533

E.K. 0000-0002-4466-1615

\section{ÖZET}

Üriner sistem konjenital anomalileri diğer sistemlere kıyasla daha sık görülür. Çift toplayıcı sistem, tek bir Wolff kanalından iki ayrı üreter tomurcuğu ortaya çıkması ile veya üreter tomurcuğunun böbreğin üst ve alt kutup parçalarıyla tam olmayan füzyonu sonucu meydana gelir. Üreter orifisinin mesane boynuna veya trigon dışında bir noktaya açılmış olmasına ektopik üreter denir. Bu olgumuzda sürekli idrar kaçırma şikayeti olan 6 yaşında kız hastanın bulguları paylaşıldı. Hastamızda sol taraflı çift toplayıcı sistem mevcuttu ve üst polü drene eden ektopik üreter infrasfinkterik olarak vaginal vestibüle açılmaktaydı. Olgumuzda ektopik yerleşimli üretere ait böbrek üst polü fonksiyone idi . Hastaya end to side üretero-üreterostomi yapıldı. Sürekli idrar kaçırması olan kız çocuklarında ektopik üreter ayırıcı tanıda düşünülmelidir.

Anahtar sözcükler: Ektopik üreter, idrar kaçırma , çift toplayııı sistem ,üreteroüreterostomi

\section{INTRODUCTION}

Urinary system congenital anomalies are more commonly seen than other systems congenital anomalies. The reason for this is urinary system rises from both endoderm and mesoderm germ layers and merges then the kidneys make ascensus. During the embryological process in the end of the 4th-week ureter bud which rises from distal mesonephric duct unites with metanephric mesenchyme blastema and generates permanent kidney. Permanent kidney ascends to the lumbal zone under adrenal glands in between 6th and 9th weeks ${ }^{1}$. Duplex 
collecting system occurs from two different ureter buds being generated from one Wolffian duct or uncomplete fusion of ureter buds' upper and lower poles.

Normally ureteral orifices should be located on vesical trigone. Ureteral orifice being opened to bladder neck or other than vesical trigon is called ectopic ureter. If the ureteral orifice opens more lateral to the normal location it is called lateral ectopia, if it opens more medial to the normal location or to lower parts of the bladder which is closer to the urethra it is called medial or caudal ectopia. It is often with a duplex collecting system. Duplex collecting system classified as complete or incomplete duplication. If ureters have two separate pyelocalyceal systems but enter to two seperate orifices in bladder it is called complete ureteral duplication, if ureters have two separate pyelocalyceal systems but enter to the same orifice it is called incomplete ureteral duplication. Incomplete ureter duplication is the most common congenital anomaly of the upper urinary system. However, complete ureter duplication has more clinical symptoms. It is more often in girls ${ }^{2}$. Ectopic ureter usually diagnosed at pediatric ages. Usual complaints are persistent and recurrent urinary tract infections, voiding dysfunctions, and urinary incontinence. Sometimes it is diagnosed incidentally by imaging techniques for different pathologies. It is seen rarely but in girls, ectopic ureter may open to vaginal vestibule and could cause persistent urinary incontinence which is unresponsive to treatment. In this case report, we present a 6 years old girl with constant dribbling of urine for 4 years.

\section{CASE REPORT}

6 years old, girl, no pathological findings in her physical examination, constant urinary incontinence (as leaking) for 4 years even after toilet training. Kidney function tests were normal. No pathologies in simple urine test. 2 times cystouretheroscopies made in different clinics for same reasons. Left pyelocaliectasis and ureter dilatation found in her urinary ultrasonographic examination. In the voiding cystouretherography vesicoureteral reflux was not demonstrated, bladder capacity was normal and the bladder neck was normal during micturition. In MR urography left duplex collecting system has been demonstrated (Figure 1). In other clinics, ectopic ureter orifice has been doubted but could not show it during cystourethroscopy. Hence, we did cystoscopy in anesthesia and did not see any ectopic ureter. In MR urography pyelocaliectasis and ureter dilatation has been found but during our left retrograde pyelography, no pyelocaliectasis or ureter dilatations were observed (Figure 2). A urogenital examination was made again but under anesthesia and an orifice was found located inferolateral of urethra which was suspected as a urether orifice (Figure 3). A hydrophilic guidewire was placed to the kidney and confirmed with scopy (Figure 4). An open-ended ureteral catheterization has been tried from the orifice but could not be accomplished. According to localization of the guidewire during scopy and retrograde pyelographic (RGP) imaging of the other ureter, the ectopic ureter has thought to be located on the upper pole. 


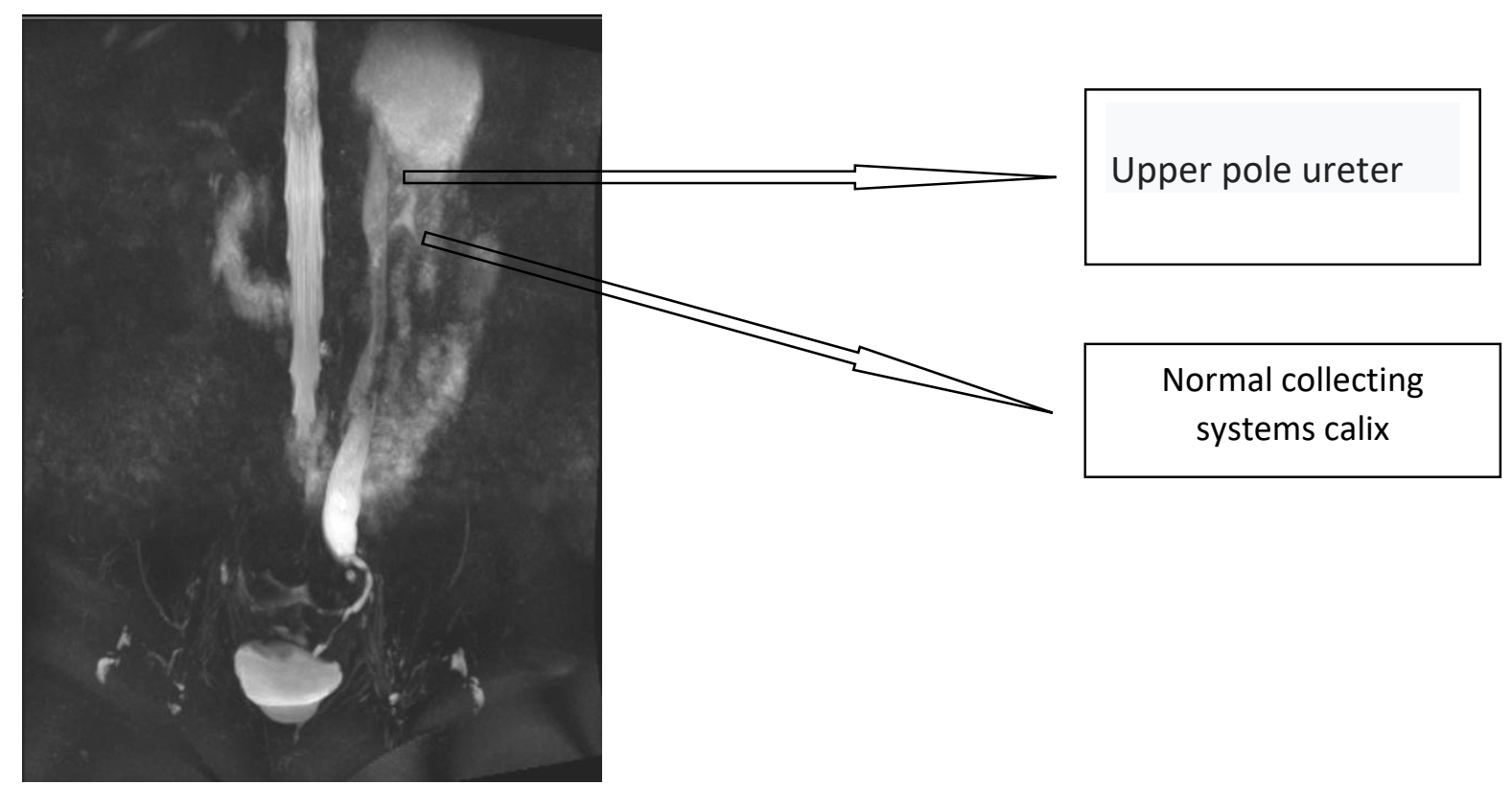

Figure 1: Duplex collecting systems image on MR urography

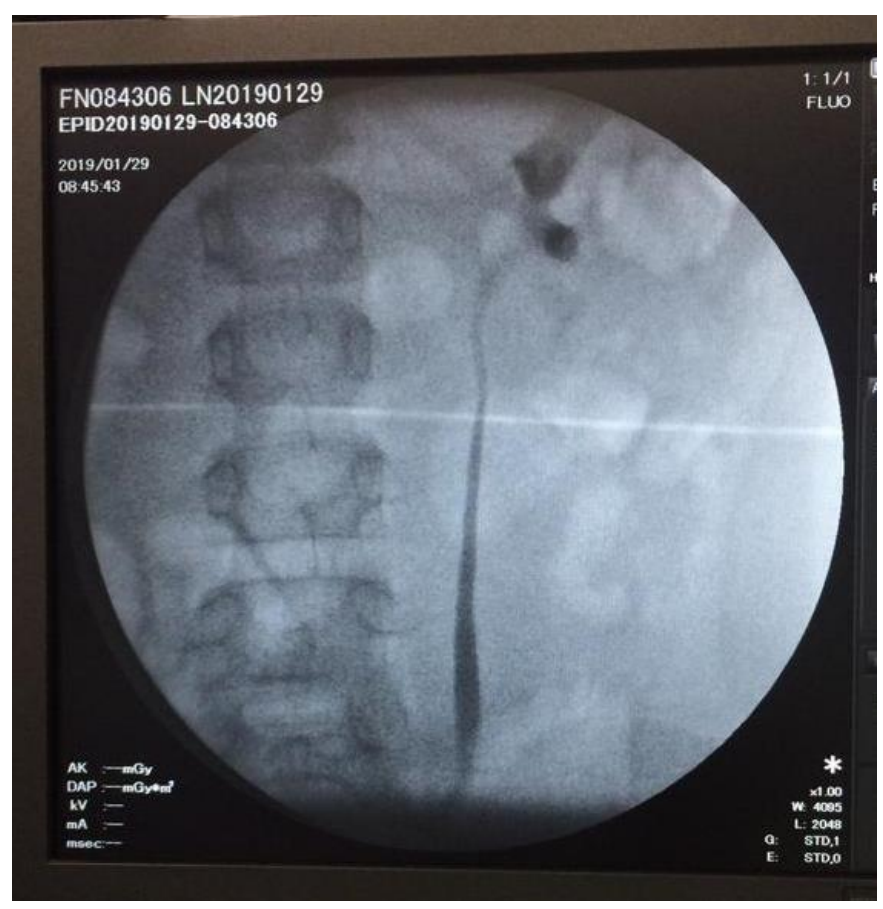

Figure 2: RGP imaging of left collecting system 


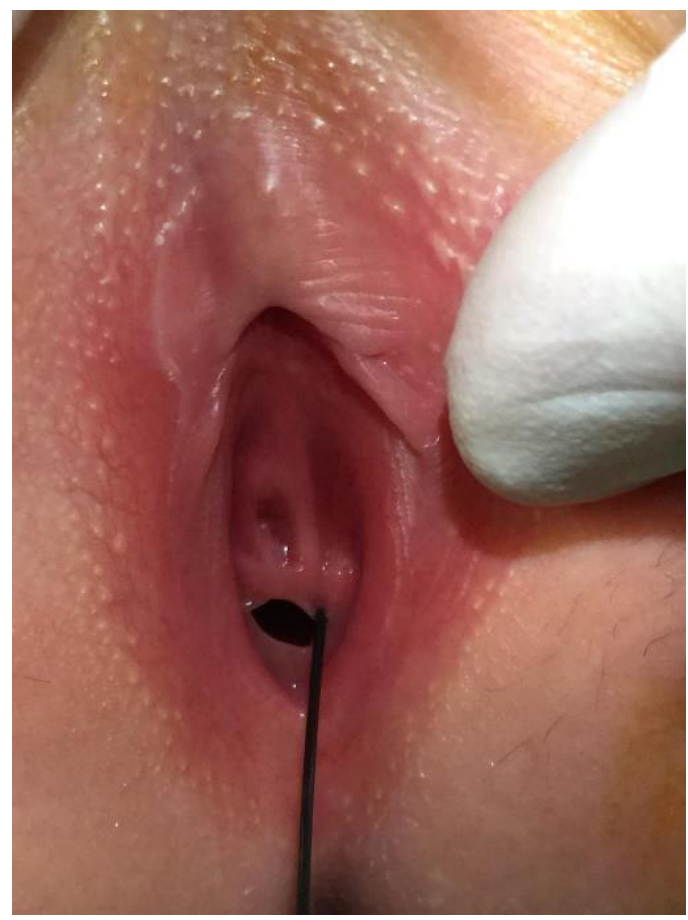

Figure 3: Sending guide from the orifice of ectopic ureter

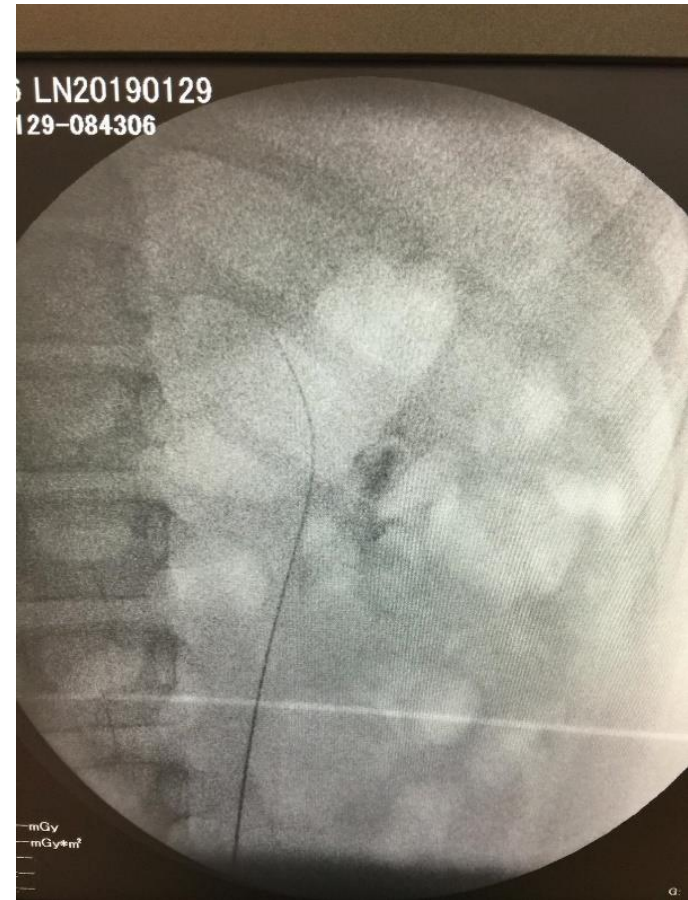

Figure 4: Sending guide from left ectopic ureter

DMSA scan made for planning the surgical procedure to the left-sided duplex collecting system (left heminephrectomy? - left ureteroureterostomy or left ureteroneocystostomy). Separated renal functions of the right kidney was $52 \%$ and left kidney was $48 \%$. Left kidneys separated polar functions were $32 \%$ for the upper pole and $68 \%$ for the lower pole. Ureteroureterostomy has been made due to the upper pole being functional which was drained by the ectopic ureter and there were no pathologies required an intravesical procedure. End-to side ureteroureterostomy made to middle segment of the ureters (Figure5-6) . $4 \mathrm{fr} 16 \mathrm{~cm}$ DJ catheter inserted 
from anterograde way. Ureteral catheter pulled of in post-op 3rd day and drainage tube pulled of in post-op 4th day. DJ catheter pulled of in post-op 2nd week. The patient was observed without complications in her post-op period.
Procedure was told to the patient in details and her legal representatives accepted the informed consent.

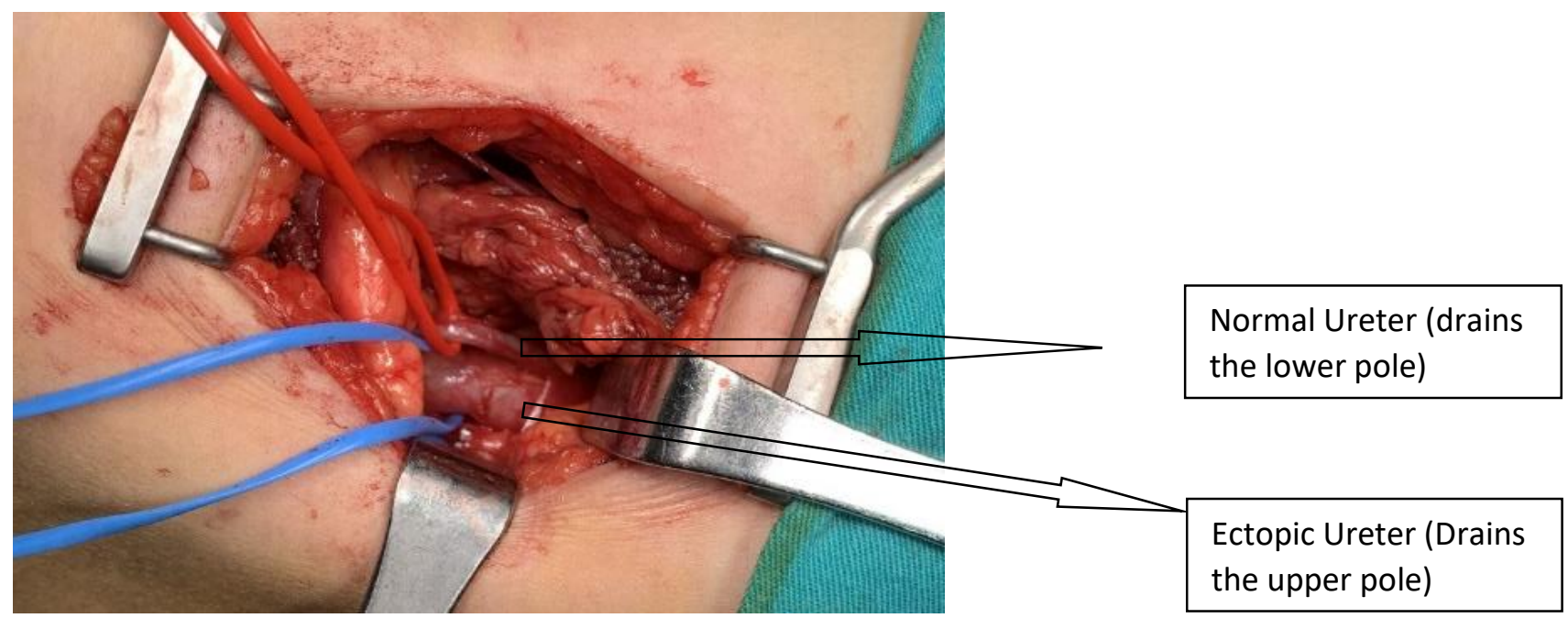

Figure 5

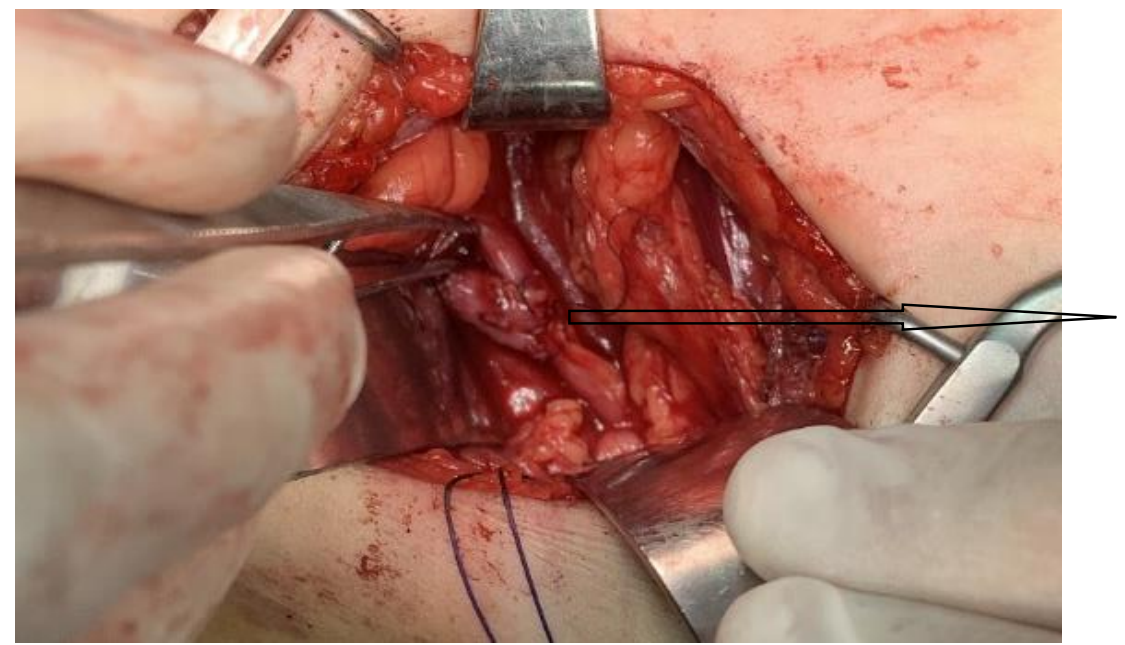

Anostomosis of ureteroureterostomy

Figure 6

\section{DISCUSSION}

Ectopic ureter is seen $0.025 \%$ in the population. Nearly $10 \%$ is bilateral. It is seen 6 times more in girls. Ectopic ureter usually drains duplex system in girls and single system in boys. In duplex systems, ectopic ureter drains upper pole (80\%). In duplex collecting systems ureter that drains the upper pole opens to the infero-medial part of the bladder and the other ureter that drains the lower pole opens to the superolateral part of the bladder according to the Weigert-Meyer law. At the same time, ureteroceles may occur in the one that drains the upper pole and vesicoureteral reflux (VUR) may occur in the one that drains the lower pole because of opening to outside of the trigon ${ }^{3}$. In boys ectopic ureter opens to bladder neck/prostatic urethra $(48 \%)$, seminal vesicle $(40 \%)$, ejaculator duct $(8 \%)$, vasa deferentia $(3 \%)$ or epididymis $(0.5 \%)$. In girls it opens to bladder neck $(35 \%)$, vaginal vestibule $(30 \%)$, vagina $(25 \%)$ or uterus $(5 \%)^{4}$. It should be remembered that in boys if ectopic ureter opens to the epididymis epididymo orchitis may be seen. In boys, the ectopic ureter never opens to the distal of the sphincter so it never causes urinary incontinence. 
In girls, ectopic ureter rarely ends in the urethra or vaginal vestibule. For this reason, an infrasphincteric ectopia may cause constant dribbling of urine ${ }^{5,6}$. If not diagnosed early this urinary incontinence can be mixed with stress urinary incontinence, overactive bladder, urinary fistule, or urethral sphincter insufficiency at older ages. When urinary incontinence is explored it should be known that it has a lot of causes and should be searched with a careful history while determining its type. In our case even there were a lot of physical examinations and endoscopies the ectopic ureter was not determined. Ectopic ureter determined with a systematic approach to urinary incontinence and careful physical examination under anesthesia.

Treatment of ectopic ureter should be determined according to the function of the pole that ectopic ureter drains in duplex collecting systems. Pole nephrectomy (heminephrectomy) is performed in the cases in which ureter opens to the nonfunctional pole. Uretero-neocystostomy (UNC) or uretero-ureterostomy can be applied when ectopic ureter drains a functional pole such as in our case. If there is a pathology in ectopic ureters opening to the bladder (vesicoureteral reflux, ureteroceles) UNC treatment should be applied. Ureteroureterostomy was applied in our case due to surgical easiness and not having intravesical pathologies.

It is argued that anastomosis should be done proximally or distally. In our case, we did proximal "end to side" uretero-ureterostomy because of the difficulty of ureters lower segments dissection and lower segment's constructed structure.
It should be remembered that girl constant dribbling of urine patients' duplex collecting systems ureter may locate ectopically intrasphincteric. If there is an ectopic ureter, approaching the duplex collecting system treatment should be considered according to renal pole drained by the ectopic ureter and intravesical pathologies (vesicoureteral reflux, ureteroceles, etc.).

\section{REFERENCES}

1. Netter FH, Kelly CR, Landman J, Machado CA. The Netter Collection of Medical Illustrations Urinary System: Volume 5: Elsevier Health Sciences; 2012;34- 36.

2. Jednak R, Kryger JV, Barthold JS, González R.: A simplified technique of upper pole heminephrectomy for duplex kidney. J Urol. 2000;164:1326-8

3. Didier RA, Chow JS, Kwatra NS, Retik AB, Lebowitz RL. The duplicated collecting system of the urinary tract: embryology, imaging appearances and clinical considerations. Pediatr Radiol. 2017;47(11):1526-38.

4. Fernbach SK, Feinstein KA, Spencer K et al. Ureteral duplication and its complications. Radiokhraphics 1997; 17:109-117

5. Albers P, Foster RS, Bihrle R, Adams MC, Kea- ting MA: Ectopic ureters and ureteroceles in adults: Urology 45(5); 870-4, 1995.

6. Blacklock AR, Shaw RE, and Geddes JR: Late presentation of ectopic ureter. Br J Urol 54: 106- 110, 1982. 